\title{
Drought Forecasting for Streams and Groundwaters in Northeastern United States
}

\section{Background}

When rainfall is lower than normal over an extended period, streamflows decline, groundwater levels fall, and hydrological drought can occur. Droughts can reduce the water available for societal needs, such as public and private drinking-water supplies, farming, and industry, and for ecological health, such as maintenance of water quality and natural ecosystems. Recent droughts in the northeastern United States have highlighted the need for new scientific tools to forecast the probability of future droughts so water managers and the public can be better prepared for these events when they happen. Two recent U.S. Geological Survey (USGS) studies provide tools that can forecast the probabilities of summer droughts for streams (Austin and Nelms, 2017) and the probabilities of groundwaterlevel declines below specified targets or thresholds (Dudley and others, 2017). These tools provide promising methods for identifying and anticipating probable streamflow and groundwater droughts specific to the northeastern United
States. USGS Water Science Centers in the northeastern United States have acted together to use these methods for numerous streamflow gages and groundwater-level monitoring wells, and to make the results of the analyses available on the world wide web.

This fact sheet describes the drought forecasting techniques used in a study to predict droughts for streamflow and groundwater in the northeastern United States.

\section{Overview}

Tools for drought forecasting were developed and applied to 1,168 streamflow gages and 23 groundwater-level monitoring wells in the northeastern United States using methods described by Austin and Nelms (2017) and Dudley and others (2017). The forecasting tools use statistical modeling approaches to anticipate and plan for potential streamflow droughts from 1 to 11 months in advance of their occurrence and groundwater droughts 1 to 3 months in advance of their occurrence.
Results from the models in the form of graphs and maps are available in an interactive USGS web tool (Kandel and others, 2019) (https://va.water.usgs.gov/ webmap/drought_ne/), which is updated monthly when the most current hydrologic streamflow or groundwater-level data are available for each location. Using constant projections of drought potential, local, state, and regional managers and planners can identify potential streamflow and groundwater droughts with extended lead time, affording the opportunity to anticipate, initiate, and adjust drought management actions ahead of an impending drought.

\section{Drought Forecasting Techniques}

Statistical analyses called logistic regression models were prepared for each gaged stream and groundwater well in the web tool. Logistic regression calculates the probability of an event occurrence, based on the predictors (explanatory variables) used in the model. Each stream forecast model provides summer month hydrological drought streamflow probabilities using streamflow data collected during the previous winter months. Groundwater well forecast models provide hydrological drought predictions using data from several explanatory variables: current and previous groundwater levels, nearby streamflow, base-flow estimates, precipitation, drought severity indices, and atmosphere-ocean indices.

\section{These tools provide promising methods for identifying and anticipating probable streamflow and groundwater droughts specific to the northeastern United States.}




\section{Streamflow Probabilities}

Maximum Likelihood Logistic Regression (MLLR) models (fig. 1) are used to predict the chance of streamflow exceeding, or not exceeding, a particular drought threshold, describe the odds of a particular outcome using a predictive variable, and estimate the probability response as a smooth function of a factor. In the development of this tool, the probabilities of daily streamflow exceeding (moving above) and not exceeding (staying below) a 20th percentile drought threshold during summer of the year (July through September) are estimated as functions of monthly mean streamflow during the previous winter (October through February). Studies have shown that well-formed MLLR models can provide accurate predictions of drought streamflow probability and that some of the best performing models deal with areas for which drought is of high concern to water-resource managers. In one ad hoc test of 5,950 predictions of September drought streamflow probabilities across the United States, using streamflow data from the previous October, the overall rate of correct prediction exceeded 90 percent (Austin and Nelms, 2017).

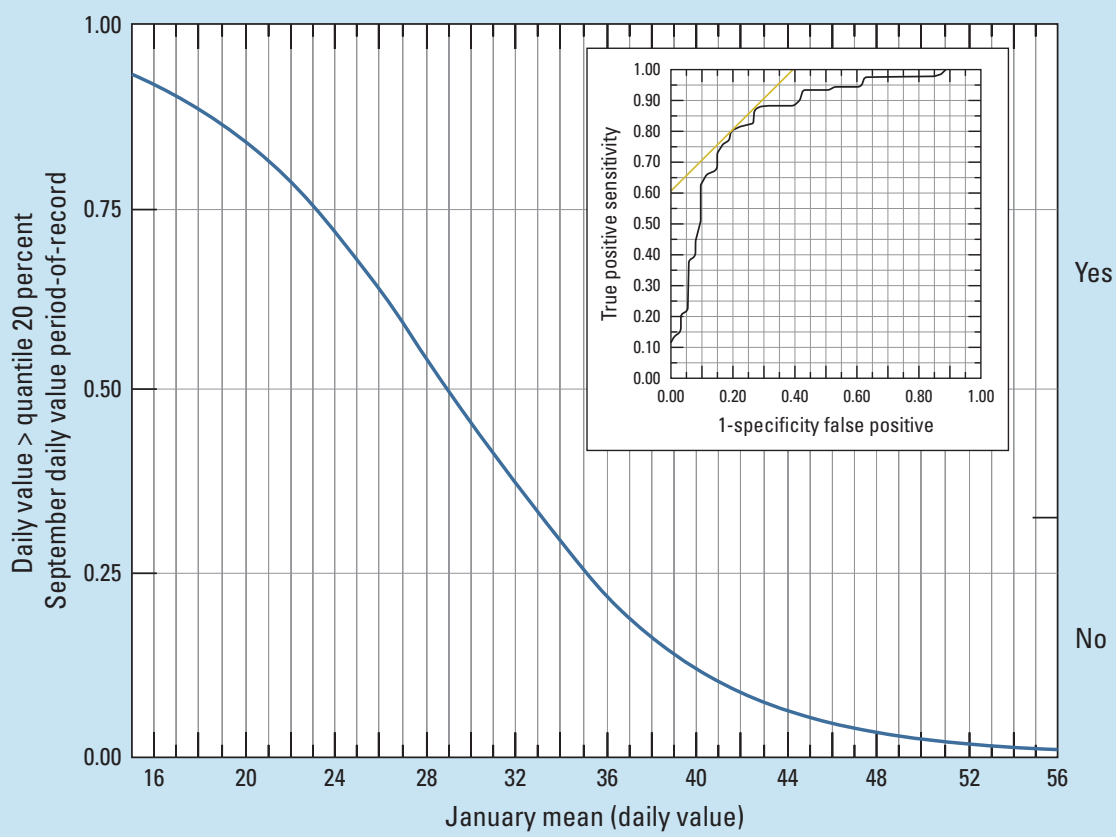

Figure 1. An example Maximum Likelihood Logistic Regression model and Companion Receiver Operating Characteristic Validation Curve (inset) with area under curve of 0.85 , indicating high prediction accuracy, estimating drought streamflow probability in September (y-axis) as a function of mean daily streamflow from the previous January (x-axis). (Station number 14054500, Brown Creek Near La Pine, Oregon, 1922-91. Daily value [DV] is the average streamflow during a single day, measured in cubic feet per second; period-ofrecord, the full interval of time over which streamflow daily values have been recorded at a particular streamgage; Yes, the probability of DV exceeding drought flow [no drought], $y$-axis fraction above the regression line; No, the probability of DV not exceeding drought flow [drought], $y$-axis fraction below the regression line) Figure modified from Austin and Nelms, (2017, fig. 6). 


\section{Groundwater-Level Probabilities}

The groundwater drought forecast models used in this study are logistic regression models that estimate the probability that future groundwater levels will be at or less than the low 10th percentile groundwater-level value among all available data for each well (fig. 2). The ability of forecast models to estimate the probability of groundwater levels at or less than the 10th percentile varies among the wells analyzed, and as a result, statistically valid predictions may be available 1-3 months into the future for any month of the year. The explanatory variables used in the forecast models represent current conditions at the time of forecasting. For example, for a 1-month forecast model, the current month-end values for groundwater levels and Palmer Drought Severity Index could provide the input data to forecast the probability that a groundwater level will be at or less than the 10th percentile threshold at the end of the next month.

\section{Accessing the Drought Probabilities}

An interactive, online map resource tool (fig. 3) providing real-time access to, and visualization of, streamflow and groundwater drought probabilities for each northeastern United States gaged basin and groundwater well included in this study is available at https://va.water. usgs.gov/webmap/drought_ne/.

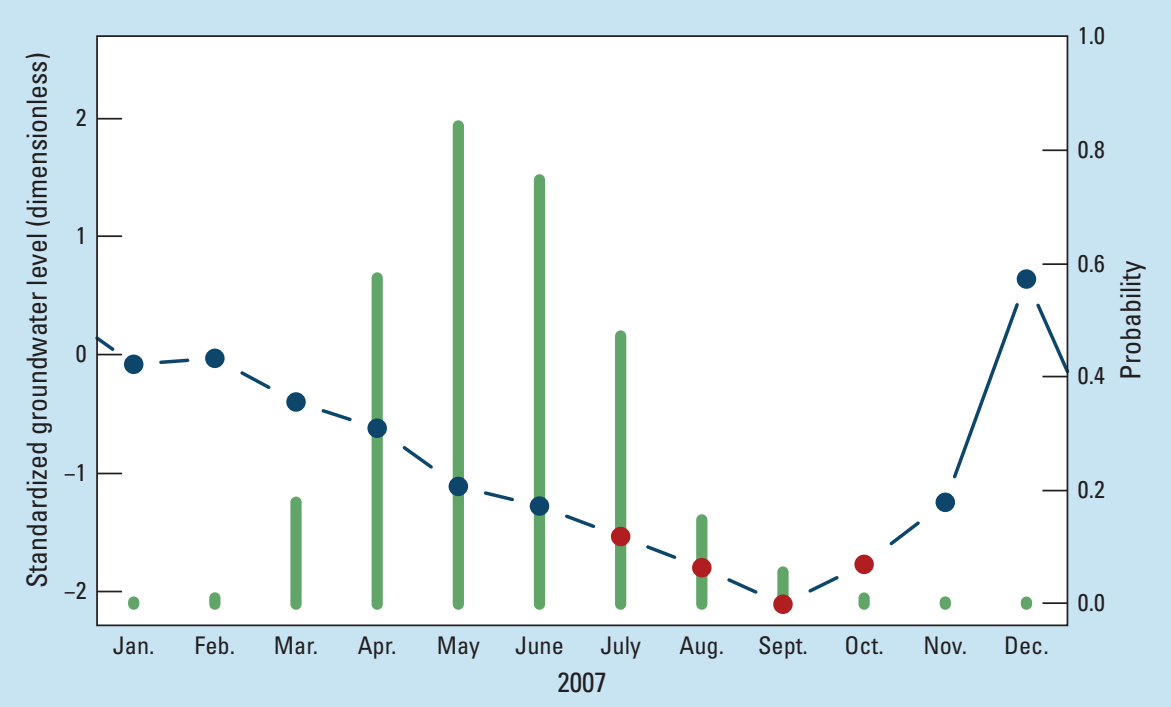

EXPLANATION

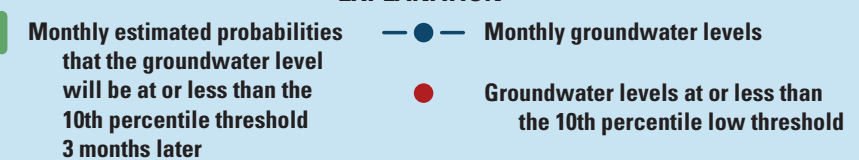

Figure 2. Example of a 3-month groundwater drought forecast model. Figure modified from Dudley and others (2017, fig. 3).

\section{Broadening Analyses to Enhance Predictions}

Additions to the data used for the models could enhance and further strengthen drought predictions. For example, adding explanatory variables such as measurements of snowpack or National Oceanic and Atmospheric Administration precipitation forecasts could strengthen the model response, as could extending and shifting the temporal reach of predictive models to months later than February and intervals larger than 1 month. Empirical testing and fine-tuning of model explanatory and response variables using attributes of unique landscape settings or particular regions of the country could improve model robustness and reliability.

Potentially significant advances in predictive capability and model utility are possible with new support from USGS Water Science Centers in the northeastern United States. 


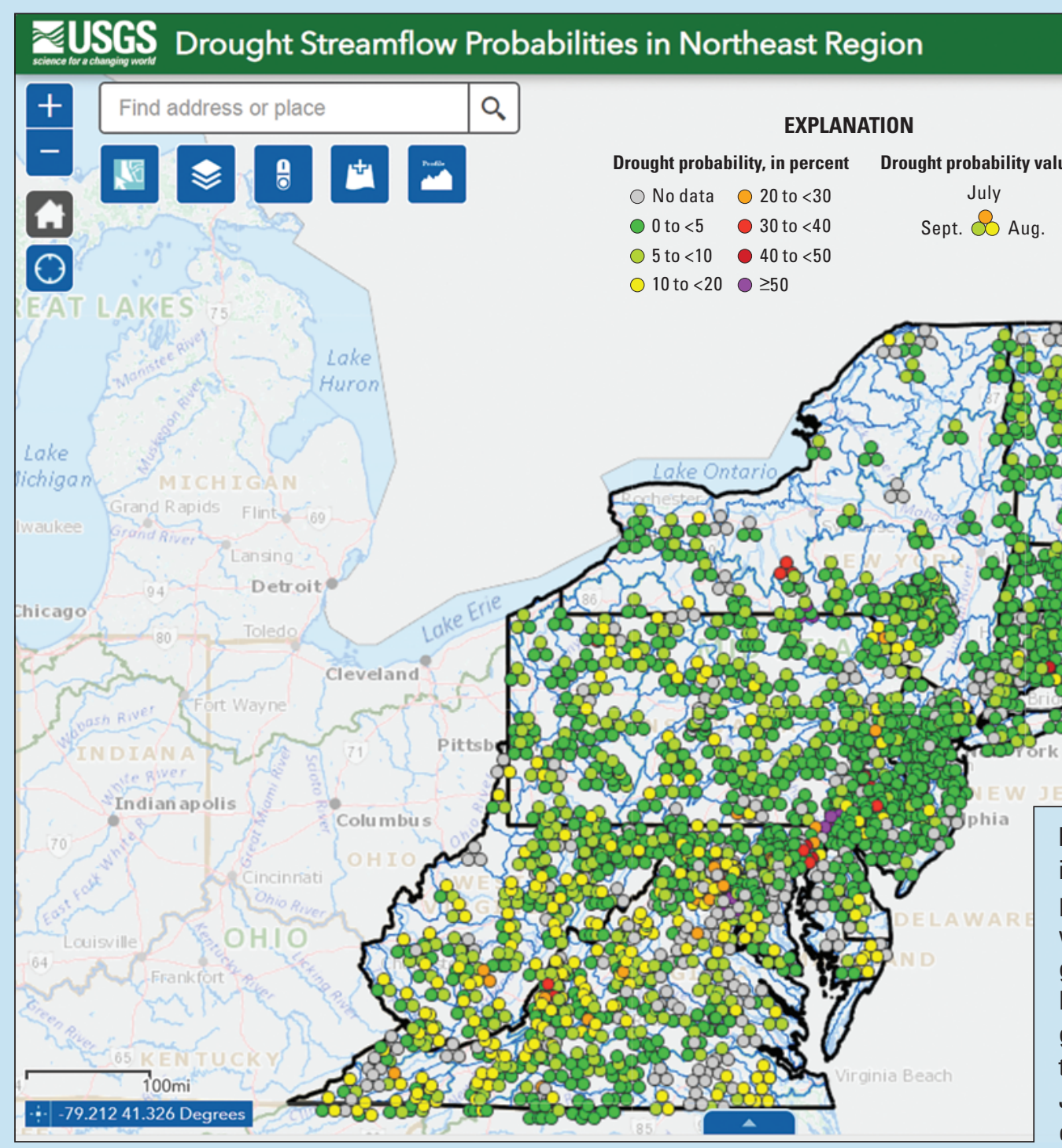

Figure 3. Example of the online interactive map resource tool that provides real-time access to, and visualization of, streamflow and groundwater drought probabilities. Drought probability values for each gaging station are shown as a triad of three color-coded circles representing July, August, and September drought estimates (Kandel and others, 2019).

\section{For More Information on the Forecasting Tool}

For sites in Connecticut, Massachusetts, Maine, Rhode Island, New Hampshire, and Vermont, contact

Director, New England Water Science Center, (603) 226-7807,

10 Bearfoot Rd,

Northborough, MA 01532,

https://www.usgs.gov/centers/

new-england-water

For sites in Maryland, Delaware, and Washington D.C, contact Director, Maryland-Delaware-DC Water Science Center,

(443) 498-5501,

5522 Research Park Drive,

Catonsville, MD 21228,

https://www.usgs.gov/centers/

md-de-dc-water

For sites in New Jersey, contact

Director, New Jersey Water Science Center, (609) 771-3901,

3450 Princeton Pike, Suite 110,

Lawrenceville, NJ 08648,

https://www.usgs.gov/centers/nj-water
For sites in New York, contact

Director, New York Water Science Center, (518) 285-5661,

425 Jordan Road,

Troy, NY 12180-8349,

https://www.usgs.gov/centers/ny-water

For sites in Pennsylvania, contact

Director, Pennsylvania Water Science Center,

(717) 730-6950,

215 Limekiln Road,

New Cumberland, PA 17070,

https://www.usgs.gov/centers/pa-water

For sites in Virginia and West Virginia, contact Director, Virginia and West Virginia Water Science Center,

(804) 261-2600,

1730 East Parham Road,

Richmond, VA 23228,

https://www.usgs.gov/centers/va-wv-water

\section{By Samuel H. Austin and Robert W. Dudley}

Banner image by Hendrik Cornelissen, Unsplash; image of stream on p. 1 by Nathan Anderson, Unsplash; image of stream on p. 2-3 by Arjan Wilmsen, Unsplash.

\section{References Cited}

Austin, S.H., and Nelms, D.L., 2017, Modeling summer month hydrological drought probabilities in the United States using antecedent flow conditions: Journal of the American Water Resources Association, v. 53, p. 1133-1146, accessed November, 15, 2018, at https://doi.org/10.1111/17521688.12562 .

Dudley, R.W., Hodgkins, G.A., and Dickinson, J.E., 2017, Forecasting the probability of future groundwater levels declining below specified low thresholds in the conterminous U.S.: Journal of the American Water Resources Association, v. 53, p. 1424-1436, accessed November, 15, 2018, at https://doi.org/10.1111/17521688.12582 .

Kandel, C., Austin, S.H., and Rapp, J.L., 2019, Drought Streamflow Probabilities in the Northeast Region: U.S. Geological Survey Web-Mapping Application, accessed April, 3, 2019, at https://va.water.usgs.gov/ webmap/drought_ne/. 